DOI 10.31718/2077-1096.21.1.123

УДК 81'373.424:81'42:616.31-028.412

\title{
Жовнір М.М.
}

\section{ПАРОНІМІЯ В НАУКОВОМУ СТОМАТОЛОГІЧНОМУ ДИСКУРСІ: АНОРМАТИВИ Й УНОРМОВАНІ ВАРІАНТИ ВЖИВАННЯ}

Українська медична стоматологічна академія, м. Полтава

У цій статmі зосереджено увагу на системі охорони здоров'я, без повноцінного й злагодженого функціонування якої неможливі існування й подальший розвиток інституту держави загалом. У полі зору авторки - мова стоматології. Підкреслено, що стоматологія має оперувати внормованою термінологічною системою, особливим, вивіреним часом, фраховим узуальним тезаурусом. Акцентовано на необхідності дотримання норм сучасної української літературної мови в науковому стоматологічному дискурсі. Указано на брак компетенції володіння науковою мовою, передовсім лексико-граматичним і стилістичним рівнями, і пізнання особливостей функціонування наукового стилю в мові стоматології. Аргументовано нагальність і своєчасність аналізу відповідності мови стоматологічних наукових і науково-методичних праць базовим фуннціональним якостям української мови й необхідності дотримання базових мовних норм авторами розвідок. Описано теоретикометодологічні підвалини вивчення мови медицини як однієї з найдавніших сфрер людської діяльності. Детально проаналізовано причини й наслідки невмотивованого послуговування паронімами - словами, близькими за звучанням, але різними за значенням і написанням: схожість звучання, семантична близькість, недостатні знання змісту одного чи кількох слів, некомпетентність мовця. 3'ясовано, що неправильне послуговування паронімами в проаналізованих дискурсивних зразках спричиняє викривлення смислу висловленого. Крім цього, запропоновано до вжитку правильні, внормовані варіанти вживання термінів-паронімів. Дослідження виконано в межах антропоцентичної наукової парадигми. У праці використано описово-аналітичний метод, загальнолінгвістичний метод наукового опису, метод порівняння, апельовано й до спеціальних лінгвістичних методів і прийомів, зокрема дискурс-аналізу. До аналізу залучено різножанрові зразки наукових текстів - meзи, cmammi, дисертації, монографііі, підручники, довідники, лекції, словники, інструкції тощо.

Ключові слова: науковий стоматологічний дискурс, мовна норма, пароніми.

Акценти в сучасному мовознавстві на антропоцентричному підході зумовлюють студіювання довколишньої дійсності в тісному, ледь не монолітному, зв'язку з мовою. Саме домінування людинозорієнтованих лінгвістичних досліджень посприяло актуалізації цікавості мовознавчого світу до «тексту, зануреного в життя» - публіцистичного, художнього, наукового, медійного, освітнього, медичного, ділового, юридичного, політичного й широкого спектра їхніх конкретних репрезентантів. Медичний дискурс подібно до решти текстів, узятих у подієвому аспекті, посідає чільне місце поміж продуктивних об'єктів для різноаспектного студіювання у вітчизняному й зарубіжному мовознавстві. На часі масштабне й багатовекторне вивчення медичного дискурсу, зокрема його комунікативно-прагматичного потенціалу й специфіки мовного втілення медичної наукової думки.

У полі зору мовознавців, зокрема лінгвокультурологів, - дослідження тісного зв'язку мови, духовних і матеріальних надбань людства, пошук їх перетинів та взаємовпливів», - зауважує Т. О. Лещенко [2]. Мова орієнтує і спрямовує наукову думку, забезпечує репрезентацію професійної ідентифікації та вправності. Фахова наукова мова стоматології обслуговує інтрапрофесійну й інтерпрофесійну усну й писемну комунікації лікаря-стоматолога.

У цій праці ми не випадково сконцентрували увагу на стоматології. Ця ланка медичної науки без упину розвивається, збагачується, употужнює й примножує здобуток багатовікових прак- тик, найновітніші світові відкриття й досягнення. Як належним чином структурована й упорядкована система наукових знань і практичних реалізацій місткого фактажу, стоматологія має оперувати внормованою термінологічною системою, особливим, вивіреним часом, фраховим узуальним тезаурусом. «Кожному досліднику, лікарю, зокрема і стоматологу, необхідні розвинуті чуття наукової мови, мовний смак, володіння науковим стилем мовлення і письма, мовними засобами наукового, насамперед вузькоспеціалізованого тексту», - висновують науковці [4]. «Опанування базових знань з граматики - це необхідна умова мовної майстерності» [1].

\section{Мета праці}

Проаналізувати термінолексеми, які перебувають у паронімічних відношеннях, і запропонувати практичні рекомендації щодо їх унормованого вживання. Для досягнення окресленої мети необхідно було вирішити такі завдання: 1) визначити теоретико-методологічні підвалини вивчення мови медицини як однієї 3 найдавніших сорер людської діяльності; 2) проаналізувати причини й наслідки невмотивованого послуговування паронімами; 3) запропонувати до вжитку правильні, внормовані варіанти вживання термінів-паронімів.

Як засвідчує історія, індивідуальне осмислення мовної інформації, мовного продукту й можливість його довільної інтерпретації не завжди відбуваються в спеціально створених умовах, наближених до ідеальних. Щоб полегшити 
мовне сприймання й осмислення прочитаного або почутого, потрібно логічно й правильно проєктувати думки вченого в лінгвальну площину й позамовну реальність.

Особливості розвитку наукової мови стоматологічного дискурсу, її унормування, відповідно - якість, не тільки цікаві, а й нагальні проблеми на сучасному лінгвальному обширі. Стрімкий розвиток суспільства, стоматологічної сфери стимулюють виражальні можливості мови, тому наразі особливої уваги в цьому аспекті потребують наукові медичні тексти, які в новітній інформаційній парадигмі помітно еволюціонують. Аналіз зразків стоматологічного дискурсу оприявив не тільки їхню стильову недосконалість, а й нехтування узвичаєними нормами.

Мова медицини постійно перебуває в центрі наукових зацікавлень вітчизняних дослідників (3. С. Булик-Верхола, К. Г. Городенська, \begin{tabular}{lll} 
Т. Р. Кияк, А. П. Коваль, \\
\hline
\end{tabular} Т. О. Лещенко, Л. Д. Малевич, Н. В. Місник, Г.В.Навчук, Л. А. Пиріг, П. О. Селігей, Б. І. Степанишин, Ю. В. Теглівець та ін.). Окремі питання, пов'язані зі специфікою функціонування мовних засобів наукового стоматологічного тексту, висвітлювали полтавці (Т. О. Лещенко, В. Г. Юфименко, Т. В. Шарбенко).

На жаль, попри увагу науковців і неабияку гостроту проблеми невідповідності актуального стоматологічного наукового дискурсу його взірцевому варіанту, ні статті, ні навіть масштабні й інформаційно місткі солідні наукові праці - дисертації, посібники, підручники, монографії, присвячені нагальним проблемам медицини, - рясніють мовними парадоксами й помилками.

Важливо, що з певних причин, які ми не беремося з'ясовувати, вкрай цінні для загального розвитку медицини наукові тексти стоматологічного дискурсу попри невідмежованість фахової мови стоматології від загального уніфікованого наукового ареалу, її здатність природно адаптуватися до мінливої сучасності й віддзеркалити найтонші позалінгвальні зрушення й дотепер не стали предметом комплексного студіювання дослідниками.

Пропоноване дослідження вкрай актуальне. Воно має виразне практичне й теоретичне значення. Результати аналізу не лише вкотре заперечать ефемерність потреби нормалізувати ситуацію в межах фахової мови стоматологічної сорери, а й убезпечать авторів різножанрових наукових текстів від позанормативного послуговування ресурсами сучасної української мови.

Насамперед нагадаємо: сучасні позамовні реалії вимагають знань і вільного володіння українською мовою. Різнорівневі законодавчі документи регулюють процес користування нею в офріційних сфрерах й визначають вимоги до працівників тієї чи тієї професійної галузі. Вони регулюють формування ідеальної мовної особистості лікаря-стоматолога, який прагне до фахової досконалості та словесної вправності.
Щоб уникнути алогічності викладу думок, не претендуючи на всеохопність і вичерпність аналізу, акцентуємо на різних рівнях системи сучасної української мови. Для глибшого аналізу обираємо невмотивоване послуговування паронімами, що спричиняє повне викривлення смислу наукової інформації.

Найбільш поширене, узвичаєне потрактування паронімів охоплює зіставлення слів, які мають будь-який звуковий збіг, випадкову схожість звукового оформлення. Подібний звуковий образ слів викликає неабиякі труднощі в науковців. На думку Т. Лещенко, «незнання їхнього точного лексичного значення призводить до неточного, а то й зовсім неправильного змістового насичення певних текстових компонентів» [4].

Як наслідок помилкового вживання через сплутування семантики й контекстуальне зближення слів за ознакою звукової подібності такі словозаміни йдуть масовим потоком із різножанрових наукових стоматологічних текстів: зібраний - забраний, лікарський - лікарняний, борозна - борозда, голівка - головка, болісний - больовий, кристалічний - криштальний - кришталевий, лабіальний - лабільний, їда - їжа, дренажування - дренування, атонія - атрезія, альвеолотомія - альвеолоктомія, девастація девіація, адсорбція - абсорбція, патогенез патокінез, дисиміляція - дисимуляція, алергія анергія, біотин - біотип - біотит, активація активізація - активність, відчуття - почуття - чуття, інтубація - інкубація, утиск - притиск тощо. Розглянемо ті, частотність активізації яких найпомітніша.

Щоб запобігти неправильному вживанню термінів-паронімів, потрібно брати до уваги значення питомих / запозичених словотвірних елементів (коренів, префіксів, суфіксів, префріксоїдів, суфіксоїдів). Паронімія в науковій мові стоматології подібна до схожості у вимові загальновживаних слів і дотичних явищ у лексикосемантичній системі сучасної української мови загалом, хоча має й свої особливості. У простудійованих зразках наукових стоматологічних текстів фіксуємо приклади й зовнішньосистемної паронімії, коли одне найменування паронімічного ряду належить до стоматологічної терміносистеми, а друге - до пласту загальновживаної лексики або термінологічного тезаурусу інших галузей знань, і внутрішньосистемної. Наприклад, грати - гратки. Перше слово традиційно дефінують «переплетенням металевих (зрідка дерев'яних) прутів, штаб і т. ін., що використовується для загорожі» [5], друге вживають на позначення геометрично правильного розміщення атомів (йонів, молекул) у кристалоподібних речовинах. Термін - в активному вжитку тих, хто має стосунок до природничих галузей, медицини, зокрема й стоматології. Залежно від того, які частинки містяться у вузлах ґратки, їх диференціюють на йонні, атомні, молекулярні, металеві, кристалічні ґратки та ін. Усвідомлюючи це й 
намагаючись точно передати структуру органа чи його частини, автори жонглюють термінами: «Грати ґратки кристала гідроксиапатиту не руйнуються, поки співвідношення Са/Р не знизиться до критичного значення 1,33», «Ґратчасті (решітчасті) пазухи розміщені між медіальними стінками очних ямок і носовою кісткою, задні ґратки лабіринту накладаються на верхній відділ гайморової порожнини, а передні біля медіального відділу очної ямки».

Атрезія - це термін, що використовується для позначення вродженої, набутої оклюзії або відсутності продовження порожнистих органів, природних отворів тіла. Натомість атонію тлумачать як відсутність нормального тонусу м'язів скелета або внутрішніх органів, втрату здатності м'язів скорочуватися. Обома термінами активно послуговуються в контексті медицини. Інколи сплутують їхнє значення, використовують у неправильних контекстах, уживають навперемінно тощо. Причин невмотивованих замін у паронімічних парах, які використовуються в розглядуваному дискурсі, удосталь: схожість звучання, семантична близькість, недостатне знання змісту одного чи кількох слів, некомпетентність мовця.

Ще один мовний парадокс - сплутування близьких за звучанням лексем ясенний і ясеновий. Загальновідомо, що ясенний - «який утворюється притисканням кінчика язика до ясен (про звуки)» [5] - не має семантичних перетинів із ясеновий - прикметника до лексеми ясен, кодисрікованої у словниковому реєстрі зі значенням «дерево родини маслинових з перистим листям і міцною деревиною, яку використовують на різні вироби» [5].

Словникове значення завжди закріплене в мові й зафіксоване у словнику. Кодифіковане в тезаурусі слово постійно функціонує в усному / писемному мовленні, тобто проявляє особливості своєї структурної організації, особливості реалізації валентних і когнітивних потенцій у процесі використання. Сполучувальні можливості лексеми ясенний потужні, а узвичаєними експлікаціями в стоматологічному дискурсі вважаємо ясенний край, ясенний формувач, ясенний сосочок, ясенний жолобок, ясенний трансплантат, ясенна борозна, ясенна тканина, зубоясенна кишеня тощо.

У фаховому науковому тексті розглядувана лексема вживається в чітко окресленому науковому значенні, вона термінологізується. Заміна ясенний на ясеновий може спричинити викривлення смислу, перекручування змісту висловленого, мовний каламбур, непорозуміння й комунікативний дисбаланс: : «Вивчали PBІ на основі опитування та за допомогою зондування ясенового ясенного сосочка, який є чутливим індикатором важкості запалення ясен», «Проводили препарування кореня під суцільнолиту вкладку з оформленням твердих тканин приясенної ділянки, закривали турундою з йодоформом та накладали пов'язку із водного ден- тину, а не пасти, щоб тимчасова пломба була із контрольованим часом твердіння і формували її так, щоб не було компресії на ясенний край».

Серед поширених термінологічних метаморфоз вирізняємо сплутування семантики близьких за звучанням лексем проникливість - проникність: «При хронічному остеомієліті щелеп спостерігається фріброзний набряк стінок судин і збільшується їх проникливість проникність, що призводить до підвищення 48 альбуміно-глобулінового показника», «Емаль в області дентиноемалевої межі, так само як $і$ в зовнішній зоні емалі, є найменш мінералізованою і найбільш проникливою проникною».

Останнім часом не лише в усному мовленні, а й у сегменті наукової й науково-методичної стоматологічної літератури помітно зросла кількість словосполучень, у яких проникність («здатний пропускати крізь себе що-небудь» [5]) має бути замінена на проникливість («який глибоко розуміє суть чого-небудь, правильно оцінює когось, щось, розбирається в чомусь; здатний проникати в сутність чого-небудь; який виражає якінебудь почуття, настрої і т. ін.» [5]).

Розмежовуючи значення обидвох лексем, автори стоматологічних праць зможуть убезпечити себе від підсвідомого нав'язування широкому загалу результатів анормативних сполучень лексеми проникливість, приміром проникливість стінок, зуба, ясен, емалі, дентину, мембрани, пульпи, тканини, судин, речовини, шарів, волокон, пучків, капілярів тощо: "Супрагінгівальна бактеріальна біоплівка викликає запалення $і$, як наслідок, підвищення проникливості проникноcmi ясен», "Цей вітамін приймає участь в клітинному диханні, зменшує проникливість проникність стінок кров'яних судин, активує фрункції кровотворних органів», "Для зменшення проникливості проникності та ламкості капілярів пацієнтам рекомендували приймати Аскорутин (по 0,5 г 3 рази на добу)».

Відрадно, що трапляються й випадки правильної, семантично виправданої, словесної сполучуваності лексеми (здебільшого на позначення особи за родом діяльності, зайнятістю) проникливий + лікар, спеціаліст, стоматолог, медичний працівник, працівник, клініцист, асистент, студент: тощо "Проникливий клініцист розуміє, що немає болю без участі психоповедінкових факторів, і ці фрактори можуть сприяти або бути причиною лицьового болю пацієнта».

У простудійованих зразках наукового стоматологічного дискурсу трапляються й інші випадки анормативної паронімічної заміни. Цікавим, на наш погляд, $є$ приклад кривавий - кровний кров'яний - кров'янистий. Лексему кровний зазвичай вживають у властивому їй значенні «який має спільних предків; рідний за кров'ю» [5]. Натомість семантика ад'єктивів кривавий кров'яний - кров'янистий потребує уточнення. 
Маючи спільну твірну основу кров - «рідина, що циркулює через серце, артерії, капіляри та вени і переносить поживні речовини і кисень до клітин тіла» [5], - кривавий потрактований як «змішаний з кров'ю» [5], кривавий / кров'яний - «який має колір крові; червоний, багряний» [5]), кров'янистий - «який містить кров; з домішкою крові» [5]). Отож, кров'яний і кривавий паралельно вживаються на позначення ознаки за кольором, кривавий і кров'янистий денотують щось, що містить у своєму складі кров: «Водночас із висипом на шкірі (в першу чергу на обличчі й за вухами), а іноді безпосередньо перед цим й на СО м'якого піднебіння, твердому піднебінні й на ділянці його переходу в м'яке виникає кривава екзантема: висипи у вигляді невеликих блідо-червоних або яскраво-червоних плямок, які мають неправильну круглу або лінійну фрорму», "Його було інфрільтровано слабким розчином анестетику, проведено розріз по перехідній складиі, з розрізу виділилася кривава піна, рану промили розчином фрурациліну 1:5000» тощо, «Місце видаленого зуба заповнене продуктами розпаду кров'яного згустку, осколками зуба або кістки, напіврозкладеними залишками їжі».

Уже не дивує, а радше пригнічує функціонування в наукових і навчальних джерелах лексеми опірний («який відзначається опором, протидією чому-небудь; непокірний» [5]) із невластивим їй значенням «який є опорою (у 1, 2 знач.); на який опирається хто-, що-небудь» [5]: «Шліфування зубних протезів, препарування опірних опорних зубів, обробка металів, фрарфору, пластмаси», «Значну роль у розумінні суті функціонального навантаження зубів у системі мостоподібних протезів, визначення плану лікування має вивчення законів біомеханіки опірного опорного апарату зуба в нормі і при патології», «За фрункціональним призначенням; за конструкцією опірної опорної частини» тощо.

Впадає в око хаотичне вживання лексем відділ і відділення. Лексикографічні джерела фріксують їхні спільні семантичні перетини, зокрема нормативним $€$ використання обидвох лексем зі значенням «частина установи або підприємства» [5]: «В операційних, перев'язочних та інших приміщеннях хірургічного відділу ефрективно застосовують ультрафріолетове випромінювання для зменшення бактеріального забруднення повітря $і$ гладких поверхонь»; «Бажано в умовах окремої палати хірургічного або інфекційного відділення, загальна дієта, їжа повинна бути м'якою».

Водночас абсолютно невмотивованим узвичаєними мовними нормами вважаємо словозаміну відділ - відділення у разі вживання першої на позначення складових елементів систем людського організму: «Ґратчасті (решітчасті) пазухи розміщені між медіальними стінками очних ямок і носовою кісткою, задні гратки лабіринту накладаються на верхній відділ гаймо- рової порожнини, а передні - біля медіального відділу очної ямки»; "Хворий 25 років отримав травму під час бійки, потрапив у щелепнолицеве відділення щелепно-лицевий відділ»; «Вона звичайно застосовується за відсутності патологічних процесів у ротовій порожнині $і$ ротовому відділенні глотки відділу глотки».

Переконані в потребі звернути увагу на словесну пару слабість - слабкість. Обидві лексеми активно вживані авторами медичних наукових текстів. Приміром, їх використовують, щоб передати самопочуття хворого, описати його стан, уживають під час розпитування пацієнта, складання анамнезу тощо. За сучасною лексикографічною традицією, слабість - це властивість і стан зі значенням слабий - «який має невелику фізичну силу; протилежне сильний; який не відзначається твердістю, стійкістю, вольовим характером; який не має великої сили, влади, великого впливу, авторитету; незначний силою, ступенем вияву», а слабкість - це властивість і стан за значенням слабкий - «який має невелику фрізичну силу; протилежне сильний; незначний силою, ступенем вияву» [5]. Тож, якщо перші значення слів збігаються («З'являються хвилювання, слабість, страх»; "Хворий 40 років скаржиться на нездужання, слабкість, головний біль, підвищення температури тіла до $\left.38,5^{\circ} \mathrm{C} »\right)$, то в решті випадків із їхньою семантикою й контекстуальним ужитком варто бути вкрай обачними, не сплутувати смисли і похідних слів: "Для перебігу цих процесів $і$ хімічних реакцій не потрібно кислого середовища, навпаки, вони більш агресивно відбуваються в слабколужному (правильно - слаболужному) середовищі»; "У той же час поширеність карієсу в місцевостях із слабкомінералізованою (правильно - слабо мінералізованою) («м'яка» вода) і сильномінералізованою («жорстка» вода) питною водою майже однакова, що підтверджує велике значення у виникненні карієсу інших чинників (наприклад, уміст фотору в питній воді)»; "Таким чином, ізолювальна прокладка захищає дентин і пульпу від впливу токсичних речовин (кислот, вільних мономерів тощо), які містяться в деяких пломбувальних матеріалах, створює перепону для теплопровідності металевих пломб, підвищує адгезивність слабкоадгезивних (правильно - слабоадгезивних) пломбувальних матеріалів».

Намагаючись точно передати причинонаслідкові зв'язки між частинами складної синтаксичної конструкції, автори віддають перевагу дієсловам пов'язувати - зв'язувати: «Під час проведення масових стоматологічних оглядів населення показники захворюваності на карієс повинні враховуватися в різних вікових групах, що пов'язано з різною схильністю до виникнення карієсу в дітей та дорослих. Крім того, заідно з рекомендаціями ВООЗ, дорослих розділяють на 3 вікові групи: молоді, особи середнього віку та особи літнього віку»; "Це 
зв'язано пов'язано з тим, що у перші роки життя дитини мінералізується більшість постійних зубів». Як бачимо, у першому реченні слово вжите правильно, зі значенням «установлювати спільність, зв'язок, взаємну залежність між ким-, чим-небудь» [5]. Натомість друге ілюструє значеннєву підміну: його загальноприйняте тлумачення «з'єднувати, скріплювати кінці чогонебудь вузлом, петлею і т. ін.» [5] не збігається з поданим вище. Використовуючи ці слова, потрібно бути пильним, щоб не спричинити значеннєвий колапс. Наприклад, у реченні «Його концентрація в слині може перевищувати вміст в крові у 30 разів, що значною мірою зв'язано пов'язано з функцією щитовидної залози» слово зв'язано автор мав би замінити на пов'язано.

\section{Висновки}

Можна скрупульозніше вишукувати в проаналізованих нами працях помилки, недоліки, вступати в дискусію щодо використання окремих слів і висловлювати дрібні зауваження. Однак у цьому немає потреби, адже одразу впадають в око прикрі огріхи у слововжитку. Ще й дотепер автори наукових доробок ніби цілеспрямовано сплутують очевидні значення слів, а потужні зусилля тих дослідників, які понад усе прагнуть підвищити рівень мовної культури їхніх наукових праць і сповільнити процес утвердження наукоподібності, засилля анормативів у стоматологічних студіях, зводиться нанівець.

Зібраний матеріал, на основі якого ми проводили дослідження, засвідчує разючу відмінність між реальним і бажаним рівнем мовної підготовки сучасного стоматолога, теоретика і практика, на фоні контрасту між його професійною і мов- ною обізнаностями. Окремого розгляду заслуговує питання, пов'язане з використанням лексикосемантичних парадигм загальновживаних слів i терміноодиниць, передовсім окремого словесного пласту - паронімів. Такий вибір невипадковий, бо прикладів невмотивованого послуговування паронімами в проаналізованих дискурсивних зразках удосталь, а наслідок - викривлення смислу висловленого.

Ми намагалися наблизити реальну компетентнісну модель мовленнєвої особистості сучасного стоматолога до взірцевої й сприяти підвищенню якості фрахової наукової продукції загалом. У цьому вбачаємо перспективу подальших досліджень із залученням до аналізу оновленого аналітичного матеріалу.

\section{Література}

1. Zhovnir M, Bondar N. Ukrayinskiy naukoviy stomatologichniy tekst u normativnomu aspekti: gramatichni vadi i praktichn rekomendatsii [Ukrainian academic text in dentistry in terms of linguistic norms: grammar imperfections and some practical recommendations]. Actual Problems of the Modern Medicine. 2019; 2 (66): 186-191 (Ukrainian).

2. Leshchenko T, Zhovnir M. Zdorov'ya vs. hvoroba $v$ konteksti slovesnoyi reprezentatsiyi tsinnisnoyi kartini svitu suchasnogo likarya [Health vs. Disease in the context of verbalization of the axiological picture of the world of a modern doctor]. Psycholinguistics. 2018; 24 (2): 163-180. (Ukrainian).

3. Leshchenko $T$. Terminy $v$ stomatolohii: imennyky cholovichoho rodu druhoi vidminy $v$ rodovomu vidminku odnyny [Terms in dentistry: nouns of the masculine form of the second abdication in the generic singular case]. Ukrainskyi stomatolohichnyi almanakh. 2017; 1: 93-96 (Ukrainian)

4. Leshchenko T. Ukrayins 'ka mova za profesi’jnim spryamuvannyam : navch. posi ${ }^{\circ} b$. dlya studenti ${ }^{\circ} v$ vishhikh

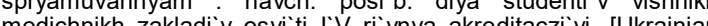
[Ukrainian language for professional purposes: textbook. for students of higher medical educational institutions of the IV level of accreditation]. Poltava: ASMI, 234 p. (Ukrainian).

5. SUM (1970-1980) Slovnyk ukrainskoi movy : v 11-ty t. [Dictionary of the Ukrainian language]. Kyiv: Naukova dumka, $11 \mathrm{t}$ (Ukrainian).

\section{Рефрерат}

ИСПОЛЬЗОВАНИЕ ПАРОНИМОВ В НАУЧНОМ СТОМАТОЛОГИЧЕСКОМ ДИСКУРСЕ: АНОРМАТИВЫ И ВАРИАНТЫ НОРМАТИВНОГО ИСПОЛЬЗОВАНИЯ

Жовнир М.

Ключевые слова: научный стоматологический дискурс, языковая норма, паронимы.

В этой статье сосредоточено внимание на системе здравоохранения, без полноценного и слаженного функционирования которой невозможны существование и дальнейшее развитие института государства в целом. В поле зрения автора статьи язык стоматологии. Подчеркнуто, что ссрера стоматологии должна оперировать четким терминологическим аппаратом, особым, проверенным временем, профессиональным узуальным тезаурусом. Акцентировано внимание на необходимости соблюдения норм современного украинского литературного языка в научном стоматологическом дискурсе. Указано отсутствие компетенции владения научным языком, прежде всего лексико-грамматическим и стилистическим уровнями. Аргументирована актуальность и своевременность анализа соответствия языка стоматологических научных и научно-методических работ базовым функциональным качествам украинского языка и необходимости соблюдения языковых норм авторами научных исследований. Описаны теоретико-методологические основы изучения языка медицины как одной из древнейших сфрер человеческой деятельности. Детально проанализированы причины и следствия немотивированного использования паронимов - слов, близких по звучанию, но разных по значению и написанию: сходство звучания, семантическая близость, недостаточные знания содержания одного или нескольких слов, некомпетентность пользователя. Показано, что неправильное употребление паронимов в проанализированных дискурсивных образцах - причина искажения смысла сказанного. Кроме этого предложено правильные, нормативные варианты употребления терминов-паронимов. Исследование выполнено в рамках антропоцентричной научной парадигмы. В работе использованы описательноаналитический метод, общелингвистический метод научного описания, метод сравнения, задействованы и специальные лингвистические методы, и приемы, в частности, дискурс-анализ. Для анализа использованы разножанровые образцы научных текстов - тезисы, статьи, диссертации, монографии, учебники, справочники, лекции, словари, инструкции.

Том 21, Випуск 1 (73) 


\section{Summary}

PARONYMS IN THE SCIENTIFIC DENTAL DISCOURSE: ABNORMALITIES AND VARIANTS OF THE NORMATIVE USE

Zhovnir M.

Key words: scientific dental discourse, language norm, paronyms.

This article focuses on the language of health care system, which is very important for modern society as its wellbeing and further development is impossible without the full and harmonious life of both an individual and a society as a whole is impossible without assistance and support of medical science and healthcare professionals. And dentistry is an inseparable part of the health care. The aim of the study is to highlight the linguistics phenomenon of paronymy in the dentistry discourse and to draw attention on the importance of correct selecting of language devices to express complex scientific thoughts, ideas and hypotheses. Therefore, the focus of this research has been shifted to the peculiarities of the development and potential of the scientific language. The peculiarities in using normative language when communicating in the dentistry domain have been studied. Special attention has been paid to misuse of modern Ukrainian literary language, especially at the lexical, grammatical and stylistic levels. It is also noted that the skilful usage of terminology is a daily duty of every qualified specialist. The theoretical and methodological bases of the dentist's professional language in the context of language professional practices and discourse development have been identified. The article analyzes the causes and effects of misuse of the paronyms - words which are partially similar by the form but different by the meaning. The article has also provided detailed practical guidance for appropriate using of paronyms. The research has been done within the anthropocentric scientific paradigm. The methodology includes descriptive and analytical methods, general linguistic method of scientific description, comparative methods, special linguistic methods and techniques, including discourse analysis as well. The study material included the texts of original theses, articles, manuals, textbooks, monographs, abstracts.

DOI 10.31718/2077-1096.21.1.128

УДК $613.8+614.253 .1$

Ільницька О.М., Попович З.Б., Ярмошук І.P. ФОРМУВАННЯ КУЛЬТУРИ ПРОФЕСІЙНОГО ЗДОРОВ'Я МАЙБУТНІХ МЕДИЧНИХ ПРАЦІВНИКІВ

Івано-Франківський національний медичний університет

Реформи в галузі вищої медичної освіти та їх інтеграція в європейський освітній простір потребують лікарів, здатних продуктивно реалізовувати свій потенціал та протидіяти негативному впливу профресійних чинників з найменшими втратами для здоров'я. Тому особливе місце у процесі формування студентів-медиків займає збереження і зміцнення їх здоров'я, створення умов для здорового способу життя. У статmі здійснений аналіз основних проблем студентської молоді у сфері збереження здоров'я на етапі профресійного становлення у закладі вищої медичної освіти, виявлені перешкоди до реалізації здорового способу життя та можливості їх подолання. В сучасних умовах навчання у закладі вищої медичної освіти нерідко створює несприятливий вплив на здоров'я студентської молоді. Це стосується навчального навантаження, відсутності у закладі вищої медичної освіти систематичної роботи по мотивації, пропаганді та фрормуванню ціннісної орієнтації на здоровий спосіб життя, а також загострена за останні роки проблема з екологією. 3 чималого переліку чинників ризику захворювань студентів вчені виділяють найбільш поширені: шкідливі звички (паління і вживання спиртних напоїв) та недостатню інформованість про здоровий спосіб життя. Все це негативно впливає на здоров'я та фізичний стан студентської молоді. Більше того, відбувається зниження адаптаційних можливостей організму, що часто приводить до розвитку хронічних захворювань. Науковці зазначають, що у значної частини молоді відбувається «експлуатація» найбільш доступного ресурсу - здоров'я. Стимули отримати хорошу освіту, профресію, хороше матеріальне становище є набагато вищими, ніж збереження та зміцнення власного здоров'я, яке в основному розглядається як інструментальна цінність, що сприяє досягненню життєвої мети. У той же час цінність, яка сприятиме довголітньому та повноцінному життю, є недостатньо усвідомленою. Отже, ціннісне ставлення студентів-медиків до формування культури профресійного здоров'я передбачає не лише створення відповідних умов для ефективного навчання у закладах вищої медичної освіти, але й мотивацію формування здорового способу життя. Це питання повинне вписуватися в програму закладу вищої медичної освіти як невід'ємна складова професійної підготовки майбутнього лікаря.

Ключові слова: лікар, студент, заклад вищої медичної освіти, професійне здоров'я.

\section{Постановка проблеми}

Необхідність дослідження проблеми формування культури професійного здоров'я майбутніх медичних працівників викликана нагальною потребою вирішення практичних питань їхньої фахової підготовки та вимогами, що висуваються до професії лікаря. Актуальність даної проблеми 